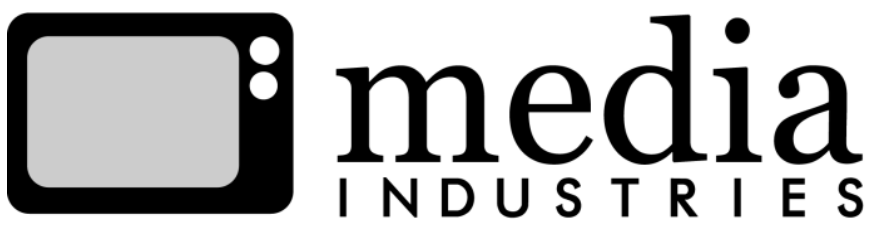

\title{
TV, Digital, and Social: A Debate
}

\author{
Jing Wang' \\ Massachusetts Institute of Technology \\ Jing [AT] mit.edu
}

\begin{abstract}
:
One of the important debates in the social media era regards the future of television. Is TV still relevant? This is both a methodological and pedagogical issue for teachers and students researching contemporary media industries. This think piece addresses the debate in the context of the US media and advertising market. Each spring, American networks sell the bulk of their inventory to advertisers for the upcoming TV seasonmore than nine billion dollars worth of advertising is sold for broadcast prime-time television alone. Internet advertising, while a smaller market, continues to grow more quickly than any other medium. As digital and social marketing catch up with TV advertising, both marketing and media professionals contest the ongoing relevance of TV as an advertising medium. This piece highlights the growing codependency and integration of TV and social media and also examines the implications of the rise of the "social TV" sector for evolving debates on the future and relevance of television.
\end{abstract}

Keywords: Advertising, TV, Marketing, Internet, Social Media, Social TV

One of the most important debates in the digital era centers on the future of TV. This question seems as urgent as the crumbling of the old journalism establishment. ${ }^{2}$ If, as Jeff Bezos avows, "The Internet is transforming almost every element of the news business," ${ }^{3}$ what is happening to the TV business, where content is also undergoing digitization?

This question is crucial to a class I teach every spring at MIT, Advertising and Media: Comparative Perspective, which examines the changing fortunes of media outlets from the perspective of advertising research. When I first offered this course a decade ago, I focused on how advertising and marketing operated in the old media environment in which TV dominated as the most favored medium for branding a product or service. Back then, media placement was an afterthought for advertisers. Parasitically embedded in the big holding companies of Adland, media service primarily involved channel planning and media buying. This division sat at the very end of the workflow of branding. Not anymore. Advertising companies WPP, Omnicom, Publicis, and Interpublic have all unbundled media from their full-service agencies. Business clients now dictate that their media investments include digital strategies. Indeed, a silent revolution has triggered an overhaul of traditional media agencies. New ad formats 
such as Twitter and Facebook marketing, mobile marketing, and online word-of-mouth have all emerged as critical components of the marketing mix, keeping step with client demands for "seamlessly integrating digital into all media plans" which is now a performance measure that advertisers rank as second in importance to "research on consumer insights." 4

Three years ago, I started restructuring my class, giving 50 percent of our time to digital. My real challenge, however, has involved interweaving discussions of broadcast and new media into each other's domain instead of treating them separately. To set us on the right course, I emphasize from the start the importance, and even the necessity, of studying media through advertising. The fact is, media and advertising are codependent: advertisers buy media spots to place advertisements and, equally important, media companies need advertisers to support content. Changing advertising paradigms - from TV-centric to digital and mobile and on to social TV - can account for the instability of some media platforms vis-à-vis others. The close relationship between content and advertising can never be overstated. After all (with a few exceptions such as premium pay TV), the ecosystem of television stands on three legs: networks, advertisers, and viewers.

This think piece reflects on the future of TV through a critical review of my advertising course. In my opening lecture to students taking Advertising and Media, I begin with this statement: TV as a medium is still relevant, and the rise of social TV as a new sector will create synergies between old media and social media that can be game changing to the industry as a whole. One crucial pedagogical task I take up in my class is to find ways of deconstructing the dichotomy between TV and digital (of which social marketing is a major component). There is a huge difference between brand building on TV and using social media to create buzz about a brand. In the contemporary context, we need both: brand building and brand extension. There is a dual danger of prioritizing one medium at the expense of the other. First, in advertisers' mad rush to be digital, they often lose sight of the importance of brand-building skills. Second, driving the train while laying the tracks (as it goes with all things digital), the clients risk forgetting that with television, a brand's infrastructure is built over time. Clients' hurried dive into digital may result in the disintegration of a brand's core values.

How best can we structure a class that treats TV and digital as two complementary media that deliver different benefits for brands? I place emphasis on teaching the basics about "brand positioning," the rationale for which is closely tied to TV as an ad medium. At the same time, I discuss recent digital campaigns by megabrands (e.g., Pepsi's "Refresh", Nike's "\#findgreatness" social campaign, and Coca-Cola's "Coke Chase" and "China Beat") side by side with their earlier classic TV commercials. This creates a set of comparisons that drives home the mutual dependency of TV and digital in shaping a brand's presence. Nobody knows better than Coke, Pepsi, and Nike-veteran TV advertisers - that TV and digital are complementary. This is the case not because these two media reach different audiences but because each engages consumers in its own way(s).

Most excitingly, I juxtapose the well-celebrated cases noted above with brands with fewer financial resources whose experimentation with digital and social is especially energizing. In comparison with the megabrands mentioned above, these brands are less 
hampered by the history of a long and successful affair with old media. Many of their daring innovations have triggered sustained viral effects. For example, Hewlett Packard's China campaign, "My Computer My Stage" (2007-2009) ran three seasons. Tipp-Ex's lighthearted "Hunter and Bear," (2010-2014), an old interactive campaign, enjoyed a renewed round of applause with several funny but thoughtful sequels. The Old Spice guy and his personalized video sequence, "The Man Your Man Could Smell Like," ruled the social media realm for the greater part of 2010. Finally, Wendy's groundbreaking, but ultimately unsuccessful, Red Wig campaign (2007-2008) pushed to the fore a central question for those jumping on the new bandwagon: are digital tactics and social reach good enough to boost sales?

Coca-Cola's answer would probably be a resounding no. Burger King's should also be a no since the King ditched Crispin, 5 its agency partner for seven years and the genius behind the Subservient Chicken viral campaign (2004-), one of the most celebrated interactive campaigns in recent advertising history. Though a widely lauded campaign, the Subservient Chicken ultimately failed to boost sales. Burger King's 2011 severance from Crispin was a sure sign that the digital game itself was changing: just going viral and altering how we think about creative is no longer sufficient. Today, interactivity for its own sake no longer moves the sales needle fast enough. Advertisers need to do more. They have to shift from treating new media as mere eye candy to focusing on making digital/social the core driver of the brand's strategic breakthroughs that transform branding practices, retail models, and, more fundamentally, business models from the inside out. Marc Speichert, the CMO of L'Oreal USA, hit the nail on the head when he observed, "Suddenly, digital becomes the catalyst for thinking differently about marketing." 6

As a means of further contextualizing and complicating our ideas regarding the digital and the social, my class scrutinizes the biggest social media blunders of recent history. This involves diving into the culture of the "always-on generation," tying demographic changes to larger media technological trends, and thinking about the social media revolution that has impacted the entertainment industry. Surely, all those interactive (and crowdsourced) ad campaigns conveyed one message loud and clear: we are witnessing a sea change in viewer demographics. Millennials want to party with brands - but on their own terms.

So how does TV withstand the unstoppable dual trend of decentralization and personalization of both content and messaging? This is one of the problematics that students in my class are asked to unravel during the semester. They are put to the test with one final class assignment for the semester where they are asked to critique the meanings of "social" at the same time that they remake an interactive marketing campaign for a brand of their choice.

Students make several important discoveries during the course. They learn, for example, that the thirty-second spot is not "on its last leg"7 despite such repeated proclamations by the press. They also find out that although the internet is the fastest-growing medium, TV continues to offer a unique scale of reach. In short, the impact that a creative television commercial has in driving brand awareness remains unsurpassed. Even Google sometimes bows to TV advertising: for example, the appearance of its commercial "Parisian Love" in the 2010 Super Bowl was a big surprise to all. Few 
students knew that the company, whose CEO once called marketing "unacceptable spending," 8 had created many lackluster TV ads before this one became a hit. Despite proclamations to the contrary, TV has continued to figure prominently in Google's strategies. Such lessons prompt me to ask the class: “Why TV?"

\section{Where Social Meets TV}

One can narrow down all the problems that television faces to one sentence: the medium does not work for narrowcasting in an age that fetishizes the micro-niche. We can also summarize the medium's longevity in an equally shorthand fashion: TV is the "last bastion of cheap, broad reach in an age of media fragmentation." 9 So what if TV were to remain intact and online were to become "TV" too? That scenario is already happening as viewership on tablets and smartphones continues to increase dramatically. There is much journalistic and industry fanfare about the dual-screen experience. But in fact, we should be talking about a triple-, or even quadruple-, screen reality. For example, imagine this scenario: I am watching the popular Chinese TV drama "The New Romance of the Three Kingdoms" (2010) on my video player while debating on my Mac with Facebook friends the superiority of this remake to the 1994 original, even as I am checking a video snippet on my iPad that reenacts the death of a minor character killed by the archvillain Cao Cao. At the same time, I could be tuning in to my iPhone to communicate with my Beijing WeChat friends about John Woo's Red Cliff, a 2008 Hollywood remake of the Three Kingdoms. And of course, I have also downloaded the original novel to my Kindle, just in case I need to read episodes that were left out of those TV and film adaptations.

As more viewers are multitasking and splintering their attention across multiple screens, TV is no longer bound to any piece of hardware. Indeed, once we realize that TV is just a state of mind, its longevity needs no further questioning and the logic behind the emergence of social TV becomes obvious. But what does social TV do? Second-screen apps like Snappy TV and tvtag allow us to watch TV while sharing our thoughts on smartphones or tablets about plot, characters, or indeed anything we watch. By making live streams and TV broadcasts social, mobile, and viral, these apps turn us into active audiences. Some optimists even opine that social chatter generated on second-screen services and apps will prompt more young viewers to watch TV in real-time again. ${ }^{10}$

For the broadcast networks, TV conversations on social media have generated data to help them adjust their programming and enabled them to produce more engaging content. Most importantly, having the knowledge of who has "checked in" to programs helps the networks shape a more personalized relationship with target viewers. A muchdebated issue is whether social buzz gooses ratings. ${ }^{11}$ Perhaps such buzz does increase ratings, but more often than not, social-TV metrics are inconsistent and should not be taken as a solution to the challenges faced by those involved in audience measurement. But all that is beside the point. Marketers who have belittled the new phenomenon and called it hype are missing the bigger picture: social TV gets consumers to engage with content and brands far beyond the broadcast window. This point takes us back to my earlier discussion about "brand extensions" of digital vis-à-vis TV. With the arrival of social TV technologies, a brand crosses over multiple platforms and drives multimedia storytelling. Moreover, social TV goes in tandem with the most obvious payoff: 
endorsements of brands from fans to their friends. Small wonder that Nielsen rolled out its Cross-Platform Online Campaign Ratings in October 2012!

Eventually, the real question for advertisers is a practical one: "Is it better to advertise on the first screen (TV), second screen (digital devices), or both?" 12 For now, the safest option is a mixed-media strategy, not least because turning the second-screen experience into a mainstream activity is a challenge. On the one hand, there are relatively few users of social TV apps and platforms. On the other hand, we know that there will not be any massive exodus of TV ad dollars until media buyers stop showing up at the Big TV upfronts - the place where networks sell the bulk of their inventory to advertisers for the coming fall season. A quick look at the ongoing debates in the digital marketing sector may help illuminate the mixed view about the viability of digital. Among the muchdebated issues, industry observers wonder whether the Web needs a TV-style hit to get the attention of TV advertisers and why it has been so hard to prove return on investment (ROI) when digital data and metrics are so abundant.

I will end my reflection on the relationship between "old television" and "digital media" with two conflicting quotes, each proclaiming that one medium outperforms the other. Leslie Moonves, the CEO of CBS Corporation, made the first statement: "The 'first screen' comes first, and there's no 'second screen' without it." 13 A second, more nuanced, pronouncement comes from Omnicom President-CEO John Wren: "We believe that 2011 was the year in which the historical distinction between so-called traditional and digital media disappeared, as we had always said it would."14 He continues: "everything we do has a digital component to it." So it seems that TV's tango with things digital takes on an unforeseen turn, thanks to the development of social TV. In this case, synergy, rather than dual, is the new catchword.

At the end of the semester, my students in "Advertising and Media" showcase the media strategies they design for a brand-repositioning campaign. I am always pleased to find that no teams choose to invest their budget exclusively in any single media outlet. A usual mix includes TV, social, radio, and billboards. Those teams that do lean heavily on TV are smart enough to develop multistation, multichannel, and multidevice strategies. Wary of underdeveloped social media metrics, most teams that work on brand luxury goods decide to give up Facebook in favor of younger platforms such as Pinterest and Vine. This move rightfully warns us of the ephemeral appeals of all digital and social platforms.

The pedagogical approach described here provides a few clues about my agenda for media industry scholarship. Apart from emphasizing the continuum of broadcast, digital, and social media and thus prioritizing the necessity of examining the media ecosystem as a whole, I believe that any thorough research on such an ecosystem has to include studies of the impact of advertising and marketing on media.

${ }^{1}$ Jing Wang is Professor of Chinese Media and Cultural studies at MIT. She is the author of Brand New China: Advertising, Media, and Commercial Culture (2008). Her coedited special issue (with Winnie Wong) "Reconsidering the MIT Visualizing Cultures Controversy," will appear in Positions: Asia Critique, 23:1 (February 2015). Wang has a dual research interest: the impact of social media on both commercial and civic communications. She is also the Director of 
NGO2.0, a China-based activist project that advocates the development of a new brand of public-interest sector that utilizes social media and nonprofit technology to build a better society.

2 In August 2013, the New York Times announced that it sold the 141-year-old Boston Globe to Boston Red Sox owner John Henry for a mere $\$ 70$ million. Almost simultaneously, the Graham family sold the Washington Post to Jeff Bezos, the founder of Amazon.com.

${ }^{3}$ Laura Norton Amico, "The Great Improvisation: Jeff Bezos, Duke Ellington, and the Washington Post," Jazz E Journalism, accessed August 7, 2013.

4 Julie Lisse, “What Clients Want," Advertising Age, April 30, 2012, C4.

5 Maureen Morrison, "Crispin's Breakup with the King Results in \$300 Million Whopper Sacrifice," Advertising Age, March 21, 2011.

6 Jack Neff, “L'Oreal Boosted Digital Spending, and It's Paying Off Big Time," Advertising Age, September 17, 2012.

7 Joseph Jaffe argued in his Life after the 30-Second Spot (Hoboken, NJ: John Wiley \& Sons, 2005) that the thirty-second commercial was dying. His was an influential view in the mid-2000s.

8 Google's Eric Schmidt once called advertising "the last bastion of unaccountable spending in corporate America." See Michael Learmonth, "Why Anti-marketer Google Has Embraced Marketing," Advertising Age, November 7, 2011.

9 Matthew Creamer, "Why 'Advanced' TV Ads Haven't Spawned a Marketing Utopia," Advertising Age, April 16, 2012.

10 Kip Cassino, “Media's Millenial Myth: 'They'll Grow into It,'” Advertising Age, February 14, 2014.

11 Simon Dumenco, "Believe the Hype? Four Things Social TV Can Actually Do," Advertising Age, April 13, 2012.

12 Shawndra Hill, "Social TV: Linking Content, Buzz and Sale," Think Insights with Google, last modified September 2012.

${ }^{13}$ Brian Steinberg, “TV's Upfront Pitch: Our Shows Offer Best Social-Media Traction," Advertising Age, May 21, 2012.

14 Bradley Johnson, "With 16.4\% Growth, Digital Is Adland's Star Performer," Advertising Age, April 30, 2012.

\section{Bibliography}

Amico, Laura Norton. "The Great Improvisation: Jeff Bezos, Duke Ellington, and the Washington Post." Jazz E Journalism. Accessed August 7, 2013. 
Cassino, Kip, “Media's Millenial Myth: 'They'll Grow into It," Advertising Age, February 14, 2014.

Creamer, Matthew. "Why 'Advanced' TV Ads Haven't Spawned a Marketing Utopia." Advertising Age, April 16, 2012.

Dumenco, Simon. "Believe the Hype? Four Things Social TV Can Actually Do," Advertising Age, April 13, 2012

Hill, Shawndra. "Social TV: Linking Content, Buzz and Sale." Think Insights with Google. Last modified September 2012.

Jaffe, Joseph. Life after the 30-Second Spot. Hoboken, NJ: John Wiley \& Sons, 2005.

Johnson, Bradley. “With 16.4\% Growth, Digital Is Adland's Star Performer." Advertising Age, April 30, 2012.

Learmonth, Michael. "Why Anti-marketer Google Has Embraced Marketing." Advertising Age, November 7, 2011.

Lisse, Julie. “What Clients Want.” Advertising Age, April 30, 2012, C4.

Morrison, Maureen. “Crispin's Breakup with the King Results in $\$ 300$ Million Whopper Sacrifice." Advertising Age, March 21, 2011.

Neff, Jack. “L'Oreal Boosted Digital Spending, and It's Paying Off Big Time." Advertising Age, September 7, 2012.

Steinberg, Brian. "TV's Upfront Pitch: Our Shows Offer Best Social-Media Traction." Advertising Age, May 21, 2012.

\section{(cc) $\mathrm{Br}-\mathrm{NC}-\mathrm{ND}$}

Copyright (C) 2015 (Jing Wang). Media Industries is an open-access, peer-reviewed, online academic journal. As such, we aim to participate in the open exchange of information. This work is licensed under a Creative Commons Attribution Noncommercial No Derivatives (by-nc-nd) License. Under this license, this work is available for sharing and noncommercial distribution provided the appropriate attribution is given. 